\title{
THE CHANGING SKILL OF NEW IMMIGRANTS TO THE UNITED STATES: \\ RECENT TRENDS AND THEIR DETERMINANTS
}

\author{
Guillermina Jasso \\ Mark R. Rosenzweig \\ James P. Smith \\ Working Paper 6764 \\ http://www.nber.org/papers/w6764
NATIONAL BUREAU OF ECONOMIC RESEARCH 1050 Massachusetts Avenue
Cambridge, MA 02138
October 1998

This research was supported in part by the National Institute of Health, the National Science Foundation, and the Immigration and Naturalization Service under grand HD33843. This paper is forthcoming in an NBER conference volume on immigration edited by George Borjas. The views expressed here are those of the author and do not reflect those of the National Bureau of Economic Research.

(C) 1998 by Guillermina Jasso, Mark R. Rosenzweig, and James P. Smith. All rights reserved. Short sections of text, not to exceed two paragraphs, may be quoted without explicit permission provided that full credit, including $\mathbb{C}$ notice, is given to the source. 
The Changing Skill of New Immigrants to the

United States: Recent Trends and Their Determinants

Guillermina Jasso, Mark R. Rosenzweig,

and James P. Smith

NBER Working Paper No. 6764

October 1998

\begin{abstract}
The objective of this paper is to describe and understand the determinants of changes in the number and quality of new legal immigrants to the United States over the last 25 years. Our main interest is in understanding the behavioral response of potential immigrants to changes in the U.S. immigration law regime (as well as in the origin-country determinants of demand for immigration to the United States) and how these affect and have affected the skill composition of immigrants. By understanding how the composition of legal immigrant flows shifts in response to immigration law changes, particularly in numerically unrestricted immigration categories, a better understanding of the consequences of future immigration reforms may be attained. We assemble a new data set based on annual INS records of all new, legal immigrants over the period 1972 through 1995. The data thus permit a new examination of the changing skill composition of legal immigrants as well as an investigation as to how these changes were influenced by alterations in immigration law regimes and, with additional data, origin-country conditions.

Inspection of our new data indicates that since the mid 1980s the average skill of new, U.S. legal immigrants has been rising relative to that of the U.S. population. An econometric analysis of a panel of country-specific measures of the skill of immigrants based on these data over the period 1972 - 1992 indicates that these changes are due in part to changes in immigration law and to the overall rise in the real purchasing power of countries outside the United States.
\end{abstract}

Guillermina Jasso

Department of Sociology

New York University

269 Mercer Street, 4th Floor

New York, NY 10003-0831

James P. Smith

RAND

1700 Main Street

Santa Monica, CA 90407
Mark Rosenszweig

Department of Economics

University of Pennsylvania

3718 Locust Walk

Philadelphia, PA 19104-6297 


\section{Introduction}

An important theme in recent research on immigration is the documentation of trends in the skills of immigrants to the United States compared to those of native-born Americans. While the original interest in that question centered on isolating the 'true' life-cycle assimilation process from successive cross-sectional surveys such as the decennial Censuses, more recently concern has been expressed that any declining relative labor market quality of immigrants is alarming in itself. Less studied has been the issue of the determinants of the changing skills of new U.S. immigrants. As in conventional models of migration, both the number and skill of immigrants to the United States are likely to be influenced by economic and social conditions in origin countries and in the destination country, the United States. However, U.S. immigration flows are also importantly affected by laws governing the number of immigrants who may be admitted and the criteria by which they are selected.

Because the standard sources of data that have been used to study the skill composition of U.S. immigrants, such as Census data, do not distinguish among the foreign-born by their legal status (legal, illegal, nonimmigrant), we do not know whether any resulting secular trends characterize legal or illegal immigrant flows alone or some unknown amalgam of the two. This distintiction is important as levels and trends in the 'labor market quality' of legal immigrant flows are quite different from those of illegal immigrants. Proposals to reduce legal immigrant flows in response to concerns about declining immigrant quality could produce the opposite result by reducing high labor market quality legal immigrants and encouraging additional low labor market quality illegal immigrant flows. In addition, conventional surveys do not contain any information on admission criteria (visa type) so that little is known about how changes in U.S. immigration admission criteria have shaped or will shape the composition of legal immigrants. And, over the past 25 years, U.S. immigration law has undergone substantial change.

Two fundamental features characterize U.S. immigration law in the period since 1921: First, the United States restricts the number of immigrants (restricting since 1921 the number from the Eastern Hemisphere, and since 1968 the number from the Western Hemisphere). Second, immediate relatives of 
U.S. citizens are exempt from numerical restriction. ${ }^{2}$ Over the years, the United States has altered both the definition of immediate relatives of U.S. citizens (e.g., in 1952 extending to U.S. citizen women the right, already held by men, to sponsor the immigration of an alien spouse outside the numerical limitations) and the system for granting numerically-limited visas (e.g., establishing a structure of preference categories in 1965 but not placing the Western Hemisphere under that structure until 1977).

These features of U.S. law combine with the overall attractiveness of the United States to produce a situation that can be described by two facts: (i) more persons would like to immigrate to the United States than current or foreseeable law permits; and (ii) whenever the immigration law regime changes, there are winners and losers among the pool of visa applicants. In such a world, we would expect to observe shifts in the number and skill of immigrants, because changes in numerical ceilings within visa categories defining who may enter change the selectivity of the overall immigration regime. For example, the law extending the preference category system of visa allocation to the Western Hemisphere should produce, mechanically, increases in the number of individuals admitted with preference-category visas, say, as principals in employment-based categories. ${ }^{3}$ That same law, however, may induce shifts in the number and skill of spouse immigrants, as persons who suddenly find themselves ineligible for a preference-category visa may come to find marriage to a U.S. citizen an attractive alternative.

The objective of this paper is to describe and understand the determinants of changes in the number and quality of new legal immigrants to the United States over the last 25 years. Our main interest is in understanding the behavioral response of potential immigrants to changes in the U.S. immigration

\footnotetext{
${ }^{2}$ A few other classes of individuals are also exempt from numerical restriction, some as a permanent feature of U.S. law (e.g., American Indians born in Canada and children born abroad to alien residents), others under temporary provisions (e.g., spouses of IRCA-legalized aliens in the special three-year program in effect in 199294). Additionally, special legislation has permitted refugees previously admitted with temporary documents to adjust to permanent resident status outside the numerical limitations.

${ }^{3}$ While some visa categories provide visas only for a single individual (for example, for the spouse of a U.S. citizen or for the parent of a U.S. citizen), other visa categories provide visas for the qualifying immigrant plus his/her spouse and minor children (for example, for the sibling of a U.S. citizen together with the sibling's spouse and minor children). In the latter case, the qualifying individual (e.g., the sibling) is known as the principal. Thus, in the employment-based categories, the principal is the individual who qualifies for the employment-based visa.
} 
law regime (as well as in the origin-country determinants of demand for immigration to the United States) and how these affect and have affected the skill composition of immigrants. By understanding how the composition of legal immigrant flows shifts in response to immigration law changes, particularly in numerically unrestricted immigration categories, a better understanding of the consequences of future immigration reforms may be attained. We assemble a new data set based on annual INS records of all new, legal immigrants over the period 1972 through 1995 . These data provide information on the occupation for many of these immigrants as well as the criteria by which they were admitted. The data thus permit a new examination of the changing skill composition of legal immigrants as well as an investigation as to how these changes were influenced by alterations in immigration law regimes and, with additional data, origin-country conditions.

Our principal analytical focus is on the behavior of persons who become immigrants as husbands of U.S. citizens. ${ }^{4}$ We choose husband-immigrants for three reasons: (i) immigrant spouses of U.S. citizens, being numerically unlimited, provide a clear signal of demand for immigration; (ii) men present a more stable unit for studying skill in a period which saw substantial changes in women's labor force participation, and (iii) spouse immigrants make up a substantial and growing proportion of all adult immigrants. Over the period we study, the average proportion of all male non-refugee immigrants aged 21 to 65 who gained permanent residence by marrying a U.S. citizen was $31 \%$, rising from $22 \%$ in 1972 to $34.4 \%$ in 1994 . The proportion has been as high as $42 \%$, in 1986 . Understanding the shifts in marital immigration thus provides a great deal of information on overall U.S. immigration. For comparison, and to assess our model, we also examine the number and skill composition of employment-based principal immigrants, a numerically limited category of immigrants that has always been a small proportion of

\footnotetext{
${ }^{4}$ U.S. citizens who marry (and sponsor the immigration of) foreign-born persons include both native-born U.S. citizens as well as earlier immigrants who have naturalized. The United States has not recorded systematically the nativity of the U.S. citizens who sponsor immigrants; a special study carried out by the U.S. General Accounting Office (GAO) on the sponsors of immediate relatives who immigrated in 1985 indicates that approximately 80 percent of the sponsors of spouses are native-born U.S. citizens. The main source countries of spouses for U.S. citizens are Mexico, the Philippines, the United Kingdom, Canada, and West Germany. Patterns differ by gender, however. For example, although Mexico is the top source of mates for both men and women, the GAO estimates suggest that while Mexico provided almost 30 percent of husbands of U.S. citizens, it provided only about 15 percent of brides of U.S. citizens. Obviously, gender differences in both travel by U.S. citizens (including military service abroad) and U.S. sojourns by foreign-born persons account for the observed differences.
} 
overall immigration but has been increased in size in recent years.

Inspection of our new data indicates, consistent with information from the U.S. Censuses and the CPS, that since the mid 1980s the average skill of new, U.S. legal immigrants has been rising relative to that of the U.S. population. An econometric analysis of a panel of country-specific measures of the skill of immigrants based on these data over the period 1972-1992 indicates that these changes are due in part to changes in immigration law and to the overall rise in the real purchasing power of countries outside the United States. Our estimates also indicate that changes in restrictions in any visa category have spillover effects on the skill composition of immigrants in other categories due to substitution by prospective immigrants across the immigration routes by which they achieve permanent residence in the United States. Among other results, we find, for example, that the restrictions on fraudulent immigration marriages, which dramatically reduced the number of marital immigrants, lowered the average skill level of immigrants entering via employment categories.

\section{What are the Trends in the Labor Market Skills of U.S. Immigrants?}

In this section, we revisit the question of what has happened to the skill composition of U.S. immigrants over the past 25 years by providing some new evidence on the skills of legal immigrants for the years 1972-1995. Whatever the factual trends in skills of immigrants, there remains an issue of to what extent the trends are determined by changes in the legal structure and rules governing U.S. immigration policy and to what extent trends reflect behavioral choices of immigrants and the U.S. population with whom they interact. We turn to this question in the next section.

The principal evidence on what has been happening to the skills of immigrants has been derived by many researchers from the 1970-1990 decennial Census. Based on this data source, a close to universal consensus has been reached -- the labor market skills of new recent immigrants has been declining significantly relative to skills of the native-born. For example, the recent National Academy report indicates that the education of recent male immigrants compared to the native-born grew from .3 of a year in 1970 to 1.4 years by 1990. Similarly, the male new immigrant wage gap expanded from 17 
to 32 percent as measured in the 1970 and 1990 Censuses. ${ }^{5}$ Similar trends exist for female immigrants.

There are a number of problems with relying solely on decennial Census or CPS data to make claims about trends in the characteristics of recent immigrants. First, the samples on which conclusions are drawn may be neither recent nor immigrant. As is well known, it is not clear whether respondents, in answering the standard question about time since immigration, are referring to their first, last, or most salient time of entry to the United States. Well-intentioned attempts to clarify the meaning of this question may further distort its usefulness for tracking secular trends. It is also well-known that some -and perhaps many -- sampled respondents in the Census or CPS are not new legal immigrants. Demographic studies have shown not only that some fraction of illegal immigrants participate in these surveys, but also that those more correctly characterized as nonimmigrants are included in the analytical category 'recent immigrants'. Since nonimmigrants and illegal immigrants have on average relatively short stays in the U.S., they are especially numerous among 'recent immigrants'. This problem is quantitatively important. For example, a recent study estimated that only $52 \%$ of those who reported that they immigrated since 1990 in the 1995 and 1996 CPS's were legal immigrants (Passell (1998)). The rest were either nonimmigrants $(10 \%)$ or illegal immigrants $(38 \%)$. Because there is great additional uncertainly about secular trends in the numbers of such people who appear in our mainstream surveys, our ability to draw unambiguous conclusions is weakened..

There is another less often mentioned problem with this reliance on Census data for this question. The ten-year periodicity between surveys means that the calendar years that end in nine are given enormous weight in our conclusions. If these years are for some reason atypical, we are on treacherous ground indeed. But more importantly, we may well be pointing in the wrong direction about trends in the skills of immigrants by knowing nothing about within decennial Census trends.

Because of these problems, we take a different approach in this paper to addressing the relative skills of immigrants issue by relying instead on yearly INS data about new "green card" recipients in that year. This data source, described below, has a number of distinct advantages as well as some

\footnotetext{
${ }^{5}$ See Smith and Edmonston 1997.
} 
disadvantages for this question. First, sampling issues do not arise since, with a few exceptions that are noted elsewhere in this paper, these files contain all new green card recipients. ${ }^{6}$ Second, unlike the Census or CPS, the population studied is well defined. In these data, new immigrants are defined as that year's new green card recipients. By definition, all such new immigrants are legal immigrants. Third, we also know the visa category under which the new immigrant was admitted. This critical information, unavailable in household surveys, allows us to separate out groups of immigrants by the admission criteria they satisfied. Numerical limits on visa types are one of the most important policy tools in setting immigration policy. Finally, INS data contain new immigrants for all years so that we are not at the mercy of survey-based time intervals. ${ }^{7}$

There is an important disadvantage to the INS data as well. The information available especially relating to the skills of immigrants is quite limited. For example, there exist no data on either education or income, the mainstays of economic analyses on this issue. The principal information pertinent to the skill issue is the new immigrant's occupation. Moreover, compared to the detail available in standard household surveys, INS occupation categories are highly aggregated, and a significant proportion of immigrants do not report their occupation. As does the Census and CPS, INS occupation categories also undergo periodic revision. Nonetheless, in our view, the advantages of the INS surveys outweigh the disadvantages, especially if the INS data are viewed as a useful complement to standard household surveys.

To construct an index of skill, we first mapped all of the occupational codes in the INS files to a common set of 25 occupational categories, which have been used by the INS starting in $1983 .{ }^{8}$ We also

\footnotetext{
${ }^{6}$ Formally, the INS data for a specified fiscal year cover persons admitted to legal permanent residence during that year; the green card (the "paper" evidence of legal permanent residence) is mailed to the new immigrant a few weeks after admission to permanent residence.

${ }^{7}$ The advantages of INS data for studying legal immigrants have not gone wholly unnoticed. Earlier studies of immigrant skills using INS data include Jasso and Rosenzweig (1986, 1988, 1995), Barrett (1996), and Duleep and Regets (1996).

${ }^{8}$ The 24-year series of immigrant cohort data available in micro files from the INS comprises cohorts in which occupation is measured in three distinct ways: In Fiscal Years 1972 and 1973, INS coded occupation using the U.S. 1960 Census detailed occupational classification; in Fiscal Years 1974 through 1982, INS coded occupation using the U.S. 1970 Census detailed occupational classification; and since Fiscal Year 1983, INS has coded occupation
} 
mapped the 1970, 1980 and 1990 Census occupation code into these twenty-five occupational categories. The temporal comparability of this mapping is not exact, an issue to which we return below. Based on the 1980 Public Use Census 1:1000 sample, we obtained the average earnings of all native-born men aged 21-65 working at least 35 hours in a "typical" week and at least 50 weeks in 1979 for each of the 25 occupational categories. These earnings were then assigned to respondents according to which of the 25 occupations they reported. An advantage of our fixed price index for evaluating skills is that any trends indicated by this measure will not be sensitive to the changing prices of skills -- a very salient labor market reality during the period 1970 through the 1990's.

\section{A. Occupational earnings of the foreign-born in the 1970-90 Censuses.}

We first apply the occupational earnings methodology to the decennial Census samples of recent male immigrants -- those with 1-5 years of immigrant experience. Table 1 lists our occupation imputed average incomes of recent Census male immigrants. This series is consistent with our earlier summary of Census-based trends. Based on our derived occupation based income, there was a steady fall in the incomes of new "immigrants". Across the full twenty year span, the income decline was 7.3 percent. This is quite comparable to a decline of $11.9 \%$ in recent immigrant hourly wages (measured directly in the Census files) between 1970-1990..$^{9}$ This comparability may be especially close since the direct wage measures include the impact of the spreading out in the price of skill.

Additional evidence that our occupation income series may reasonably characterize time series trends is contained in Table 2 which lists average occupation incomes by major region of residence. The first panel in this table documents the changing composition of recent immigrants at least as revealed in the decennial Censuses. The proportion of Census-defined recent immigrants of Mexican origin increased significantly (especially between 1970 and 1980) as did immigrants from other NorthAmerican countries (especially between 1980 and 1990). ${ }^{10}$ Europe was the principal region of decline as

using a 25-category classification based on the U.S. 1980 Census detailed occupational classification.

${ }^{9}$ See Smith and Edmonston (1997), Table 5.2.

${ }^{10}$ The principal source of other North American population growth were immigrants from Central America and the Caribbean. 
the fraction of new immigrants who were from European countries fell from $32 \%$ (1970) to $12 \%$ (1990). Throughout the entire period, Asians represented a significant fraction of new immigrants.

Not surprisingly, occupation incomes of Mexican-origin immigrants stand out as being particularly low. The rising fraction of immigrants from Mexico over this period indicates that there were non-trivial composition effects in the immigrant pool, an observation that must always be taken into account when describing trends. There were also strong within-region trends in occupation incomes (downward) in the other North American and Asian regions which largely reflect the changing composition of immigration within these regions.

However, some hint that not all may be so clear and neat is contained in the 1990 column of Table 1 which separates recent immigrants into the very recent (1-3 years) and the not quite so recent (45 years). ${ }^{11}$ In that year, more recent immigrants actually have higher occupation based incomes than those who reported that they arrived during 1986 and 1985 . While this disparity could reflect a rapid and already completed selective out-migration of the more skilled among the original cohort of 1986 and 1985 immigrants, it could also signal some within-period reversal of trend. Although Census data cannot resolve this issue, the INS immigrant files are ideally suited for the task.

\section{B. Occupational earnings of new legal immigrants and the U.S. population 1972-95}

To assess how the skills of legal immigrants have changed on an annual basis over the period, we use all of the available public use files containing official administrative micro-data on persons admitted to legal permanent residence in Fiscal Years 1972 through 1995 (U.S. Department of Justice 1997). ${ }^{12}$ The population covered by the data sets consists of all persons admitted to permanent residence during the fiscal year, including both new arrivals in the United States and persons adjusting their status to permanent residence from some other legal temporary or illegal status, except persons who became

\footnotetext{
${ }^{11}$ This breakdown is not possible in the 1980 and 1990 Census.

${ }^{12}$ Until 1976, the Fiscal Year started on 1 July of the preceding year and ended on 30 June; starting in 1977, the Fiscal Year runs from 1 October of the preceding year to 30 September.
} 
permanent residents through the two IRCA legalization programs (Section 245(a) and SAW). ${ }^{13}$ The data sets include information on the immigrant's age, sex, country of birth, visa class, and occupation- the single indicator of skill. For two of the 24 years covered by the public use files (Fiscal Years 1980 and 1981), a subset of the records are missing information on some variables, of which sex and occupation are pertinent to our analysis. ${ }^{14}$

For all years between 1972 and 1995, all new immigrant men aged 21-65 in the INS files were assigned an income based on their reported occupation and 1980 Census mean incomes in these occupation cells. To detect trends in relative skills of new immigrants, it is necessary to have a comparison group in each year. The 1972-1995 March CPS files were used to obtain this comparison group. From these files, a sample of men aged 21-65 years old were selected and each was assigned an occupation based income using the same occupation groupings as in the INS. ${ }^{15}$

The occupational earnings for all new immigrants and all CPS men aged 21-65 are presented in Figure 1a. The CPS income series is straightforward to describe. With the exception of a discrete downward jump in the series between 1982 and 1983, the trend consists of a small but steady rise in CPS male occupation incomes. The timing of the jump is also easy to explain -- between 1982 and 1983, CPS switched from the 1970 to the 1980 Census occupation coding system. This change represented one of the largest revisions ever undertaken by the Census in their occupational coding. While we have attempted to make the coding systems as comparable as possible, strict comparability is simply not

\footnotetext{
${ }^{13}$ INS Public Use immigrant data files exclude IRCA-legalized persons. IRCA-based adjustments to permanent resident status started in FY 1989, peaked in FY 1991 (over one million), and continue at a trickle (for example, 4,267 in FY 1995). Total IRCA-based adjustments to permanent residence, through FY 1996, number 2,684,892, of whom 59 percent are Section 245(a) cases (U.S. Immigration and Naturalization Service 1996).

${ }^{14}$ Approximately a fifth of the records have missing data. For example, among men aged 21-65 admitted with spouse-of-citizen visas, information on sex and occupation is missing for 17.4 percent in FY 1980 and 22.88 percent in FY 1981.

${ }_{15}$ Nativity is not available for most of the CPS years. While it is unlikely that the aggregate trends would be affected by the inclusion of immigrants in the CPS files, we also computed a series for non-hispanic men (a variable that is available in all CPS years). Although the level of the income series for non-hispanic men is somewhat higher, the time series trend is identical to that described in the text for all CPS men.
} 
possible. ${ }^{16}$ This non-comparability produces about a $\$ 250$ downward shift in the CPS series between 1982 and 1983 and will also lead to discrete shifts in the INS income series as well. Putting aside this complication, we see that incomes of the all male comparison group rise very slowly across these two decades.

This stability in the CPS series stands in sharp contrast to the volatility in the INS income trends for all immigrants. While the INS and CPS income series start out about the same ${ }^{17}$, the INS immigrant series is far less stable and undergoes a pronounced downward shift between 1977 and the mid 1980s. ${ }^{18}$ Beginning in the late 1980s, however, the trend reverses and the 1990s witness rising occupation based incomes of immigrants both absolutely and relative to the U.S. male working population. Instead of declining relative quality of immigrants, the decade of the $1990 \mathrm{~s}$ is more correctly described as one of rising relative immigrant quality. The INS occupation income series also demonstrates that the two Census years within its time span -- 1979 and 1989 -- provide a decidedly unrepresentative portrait of secular trends. The Census and INS data do not conflict in their description using these two years -- both show a dramatic quality decline. But these years clearly maximize the decline and obviously miss the subsequent recovery.

It has been well documented that even recent immigrants are a very heterogenous population across many dimensions -- income, schooling and country of origin to name just a few. A less appreciated -- but perhaps more fundamental -- manner in which immigrants differ involves the visa categories under which they are admitted. Even if we ignore the impact of trends in illegal immigrants that confound most household surveys, trends in the numbers and characteristics of legal immigrants are an uncertain amalgam of a set of diverse but specific immigration visa categories and the rules and behaviors that are associated with them. The type and number of new immigrants admitted in any year

\footnotetext{
${ }^{16}$ For details of the changes, see "The Relationship Between the 1970 and 1980 Industry and Occupation Classification Systems," Technical Paper 59. U.S. Department of Commerce. Bureau of the Census.

${ }^{17}$ The fact that the series for immigrants and all men are closer than Census data would suggest may partly reflect the exclusion of illegal immigrants from the INS data.

${ }^{18}$ Note the downward jump in the INS series between 1982 and 1983, a consequence once again of the shift in occupation coding.
} 
reflect policy decisions about such disparate subjects as refugees, diversity immigrants, family reunification, and needed 'skills'. Trends in the types of immigrants admitted within these quite disparate categories may reinforce each other during some time periods, but counteract each other at other times. Understanding what drives the aggregate trends requires understanding the important sub-categories that make up the yearly totals.

The heterogeneity of the categories can be most simply illustrated by subtracting from our aggregate time series immigrant trend a single category of immigrants -- refugees and asylees. Decisions about the number and types of refugees and asylees admitted are mostly not economic, but a reaction instead to political crises elsewhere and our sense of responsibility to the affected groups. The influx of Vietnamese immigrants after the end of the Vietnam War and Russian immigrants with the collapse of the Soviet Union are but two of the more prominent recent examples. No doubt, other crises will develop in the future in some part of the world and some new mix of refugees will arrive. Consequently, trends in the numbers and 'quality' of refugee immigrants are quite episodic in nature and do not reflect long-run trends in non-refugee U.S. immigration policy, the primary focus of our paper. For this reason, Figure 2 plots income trends for non-refugee immigrants.

The occupation immigrant income series in Figure 2a departs from that depicted in Figure 1a in levels and, to a lesser extent, in secular trends. Especially in the early years, immigrant incomes now exceed those obtained in the CPS. This reflects the fact that, on average, refugees are relatively low skilled and low income immigrants. They are certainly not typical of the combined family and employment based immigrants. In this revised series, there are some sharp year to year swings during the mid to late 1970 s, with a particularly sharp drop between 1977 and 1978 . However, even this revised series that excludes refugees indicates a rise in the 'quality' of new immigrants during the $1990 \mathrm{~s}$.

Figures $1 \mathrm{a}$ and $2 \mathrm{a}$ actually overstate the differences between the labor market quality of native born and immigrant workers. As mentioned above, there is a downward jump in these series beginning in 1982 that is solely due to changes in Census occupational coding. One method of eliminating this problem is to force the 1982 incomes to be equal those in 1983 for both immigrants and native-born workers alike. With these adjusted figures (Figures $1 b$ and $2 b$ ), the quality of legal male immigrants 
appears to be either equal to or above that of native-born male workers for most of the last 25 years. This is especially so if the very special case of refugees are taken out of the comparison as in figure 2 . Legal immigrant labor market quality may have been declining during the 1970 s and early 1980 s, but this decline started when the labor market quality of legal immigrants was most likely above that of native-born workers. At no point during this period of decline did the labor market quality of male immigrants dip significantly and persistently below that of native-born workers.

\section{Occupational earnings of recent immigrants in the CPS, 1994-97.}

Some confirmation of the recent trends documented in the INS surveys about the rising quality of immigrants can be obtained from the March CPS files for the years 1994-1997. Starting in 1994, the Current Population Surveys incorporated a number of changes that made these surveys much more useful for immigrant research. In particular, questions were added concerning immigrant status and the number of years since immigration. While containing much smaller sample sizes than the decennial Census files, these recent CPS innovations make that data much more useful. Table 3 lists occupation based incomes for recent male immigrants aged 21-65 in these four CPS years. These occupation-based incomes were based on the same categories (and 1980 mean incomes) used to predict incomes in the decennial Census and INS files. Consistent with the trends in INS data, male immigrant incomes (and hence their quality) rose steadily from 1994 to 1997.

Supporting evidence for the rising quality of recent immigrants is also obtained from the fact that more recent immigrants in any cross-section have higher incomes than those who arrived a few years earlier. It turns out that while for most of the last decade economists have been highlighting the issue of the declining quality of recent immigrants, the quality of new male immigrants has actually been rising. ${ }^{19}$

\section{U.S. Immigration Law Regimes}

To understand the trends and changes in the numbers and skills of new immigrants in the period 1972 to 1995 , it is necessary to also understand the features of and changes in U.S. immigration laws.

\footnotetext{
${ }^{19}$ Additional evidence that immigrant skills have turned upward is found in Funkhouser and Trejo (1995) and Barnett (1996).
} 
This period lies in the era of worldwide numerical restriction, four years having passed since the Western Hemisphere was brought under the restriction umbrella. For the whole of this period, immigrant visas were allocated under the two-pronged system consisting of numerically unlimited visas for the immediate relatives of U.S. citizens (defined as the spouses, minor children, and parents of adult U.S. citizens) and numerically limited visas for other prospective immigrants. Rules for allocating numerically limited visas, however, changed during the period, as did rules for spouse immigrants; and other legislation produced additional alterations in the law regime. In this section, we briefly describe the major regime changes during the period.

\section{A. Regime Changes in Allocation of Numerically Restricted Visas.}

At the start of the period, in 1972 , the ceilings on numerically restricted visas were 170,000 for natives of the Eastern Hemisphere and 120,000 for natives of the Western Hemisphere; and numerically restricted visas were allocated in two distinct ways, according to Hemisphere of origin. For natives of Eastern Hemisphere countries, the law prescribed a system of preference categories, with country ceilings; the preference categories included four family-based categories, two employment-based categories, a refugee category, and a nonpreference (or residual) category. Each independent country had a 20,000 annual limit. For natives of the Western Hemisphere, there were no country ceilings, and visas were allocated on a first-come/first-served basis, with some employment or asset screening.

Legislation enacted in 1976, effective in 1977, extended the preference category system and country ceilings to the Western Hemisphere. Initially, each Hemisphere retained its own separate ceiling (170,000 for $\mathrm{EH}$ and 120,000 for WH). Legislation enacted in 1978, however, brought both Hemispheres under a single worldwide numerical ceiling of 290,000 (exclusive of immediate relatives, refugees, and other special immigrants), effective in Fiscal Year 1979. Subsequently, the Refugee Act of 1980 removed refugees from the preference category system and reduced the worldwide ceiling to 270,000, effective in 1981 (with a transition ceiling of 280,000 in FY 1980).

The two employment categories under the 1965-1990 preference-category system were the third preference category, designated for "members of the professions of exceptional ability," and the sixth preference category, designated for "workers in skilled or unskilled occupations in which laborers are in 
short supply in the United States," plus, in both cases, the principals' spouses and minor children. The maximum number of visas allocated to each category was ten percent of the overall ceiling. Thus, in the years before the worldwide ceiling was established, the ceilings for all occupation-based visas were 34,000 in the Eastern Hemisphere (a continuation of their existing limit) and 24,000 in the Western Hemisphere. In 1979, the worldwide ceiling for these visas was the combined total of 58,000, and in 1981 it was reduced to 54,000 .

The preference category system itself was radically restructured again by the Immigration Act of 1990, effective October 1991. Especially relevant to the analysis in this paper was a triple shift in employment-based visas. First, the total number of employment-based visas available to qualified persons plus their accompanying family members was increased from 54,000 under the old law to 120,120 -- more than a twofold increase..$^{20}$ Second, employment-based visas were made available to multinational executives. Third, the maximum number of employment-based visas available to unskilled principals plus accompanying family members was reduced from 27,000 to 10,000 -- a 63 percent reduction. ${ }^{21}$

Of the changes within each preference category system, one is pertinent to an analysis of skill levels, and that is the legislative provision which severely restricted the granting of employment-based visas to foreign physicians. Under the provisions of the Act of October 12,1976, effective 10 January 1977, physicians are now required to have passed Parts I and II of the National Board of Medical Examiners Examination as a condition of eligibility for an employment-based visa. ${ }^{22}$

\footnotetext{
${ }^{20}$ Under the 1990 Act, the number of employment-based visas is 140,000 ; of this number, however, only 120,120 are for the first three employment preferences, which are the categories corresponding to the old system's employment preference categories. The fourth and fifth employment preference categories in the new law cover a subset of the special immigrant class which was numerically unlimited in the old law plus several new classes (U.S. Department of State 1992, Appendix F).

${ }^{21}$ The old law's sixth preference category allowed 27,000 visas to both skilled and unskilled workers in short supply (and accompanying family members). Under the new law, the unskilled portion is allowed 10,000 . Thus, under the old law, the maximum number of visas for unskilled workers would be 27,000 , in the case where no skilled workers applied.

${ }^{22}$ See Jasso and Rosenzweig (1995) for description of pertinent provisions of the 1976 legislation as well as follow-up legislation, which exempts from the examination requirement physicians who were already practicing in the United States in a nonimmigrant status as of January 1978.
} 


\section{B. Regime Changes in Allocation of Numerically Unrestricted Visas to Spouses of U.S. Citizens.}

For the entire period under study, U.S. citizens (of both sexes) were entitled to sponsor the immigration of their foreign spouses outside the numerical limitations. The steep increase in the number of immigrants admitted as spouses of U.S. citizens (hereafter simply "spouse immigrants") -- from 25,000 in 1965 to 55,620 in 1975 and 124,093 in 1985 -- coupled with a suspicion that at least a portion of spouse immigrant cases were the result of fraudulent marriages led to enactment of the Immigration Marriage Fraud Amendments in 1986. The 1986 amendments stipulate that spouse immigrants married less than two years receive a conditional visa; to remove the conditional status, such immigrants must apply to the U.S. Immigration and Naturalization Service in the 90-day period preceding the second anniversary of their having been admitted to conditional immigrant status.

\section{Other Changes in the Immigration Law Regime.}

At the start of the period under study, persons who had lived illegally in the United States since 1948 could petition for adjustment to permanent resident status under the so-called registry provision. During the decade of the 1970 s, concern increased that there was a large and growing population of illegal aliens. The Immigration Reform and Control Act (IRCA), enacted in 1986, updated the registry date to 1972 and provided two major legalization programs: (i) a two-phase legalization program for persons who had resided continuously in the United States since before 1982 in an illegal status (the Section 245(a) legalizations); and (iii) a legalization program for two groups of special agricultural workers (SAWs) who had worked in U.S. agriculture for specified durations in the years 1984 to $1986 .{ }^{23}$ The application periods for the two legalization programs were from May 1987 to May 1988 for the pre1982 applicants and from June 1987 to November 1988 for the SAW applicants (though there were late filings).

During the legalization application period and in its aftermath, two things came to be widely believed: (i) that only a fraction of Section 245(a)-eligible aliens came forward, either for fear of the authorities or through inability to pay the processing fees; and (ii) that only a fraction of the SAW-

\footnotetext{
${ }^{23}$ For simplicity, the Section 245 (a) cases will be referred to as "pre-1982" cases.
} 
legalized aliens had actually worked in agriculture. Evidence in support of the first notion includes the large number of petitions filed by legalized aliens, after adjusting to permanent resident status, to sponsor their spouses and children. ${ }^{24}$ As for the second notion, evidence from the National Agricultural Worker Surveys, which have failed to find sufficient SAW-legalized individuals currently working in agriculture, suggests that SAW-legalized persons have Ieft agriculture, if not the United States (Mines, Gabbard, and Steirman1977).

Two other changes in the immigration law regime pertinent to analyses of spouse immigrants are: First, IRCA-legalized aliens started becoming eligible to naturalize in 1994. Thus, spouses and minor children currently in the numerically-limited family second-preference visa backlogs would shift to spouses and children of U.S. citizens, introducing to the spouse-of-citizen flow a new segment, starting in FY 1995. Second, the 1990 Act instituted more stringent provisions on sponsorship of immigrants, and these become a contractual obligation in 1996, under provisions of the Personal Responsibility and Work Opportunity Reconciliation Act of 1996 and the Illegal Immigration Reform and Immigrant Responsibility Act of 1996.

Finally, there were two major changes in the rules by which foreign-born persons who are eligible for permanent residence and who are already in the United States may adjust their visa status. First, the same law that extended the preference category system to the Western Hemisphere in 1977 also extended to Western Hemisphere immigrants the right to adjust status in the United States (without returning to their origin country first). Second, legislation enacted in 1995 made it possible for persons eligible for permanent residence but living illegally in the United States to also adjust their status without leaving the country (with payment of a penalty fee).

\section{Immigration Law Regimes and Individual Behavior}

In this section we describe the expected effects of the major changes in the immigration law

\footnotetext{
${ }^{24}$ The surge in applications led to enlarged visa backlogs in the family second preference category (which covers the spouses and minor children of permanent resident aliens) and to special legislation designed to provide relief, such as the three-year legalization dependents transition program and the provision to exempt a portion of them from the country ceiling).
} 
regimes that have occurred in the past 25 years on spouse immigrants and, for contrast, on employment immigrant principals. To understand the strategic behavior of immigrants, these two immigrant categories stand out. For the vast majority of the world's population who are not candidates for admission to America, because they do not have an existing relative there, these are the only two legal ways to obtain permanent residence. In general, there are both direct and indirect effects of law changes on immigration flows. The direction of direct effects is evident from the provision of law. The direction of indirect effects, however, depends on behavioral responses to the new regime, and, in the case of effects on average skill, on differences in the skill configuration between particular pools of prospective immigrants.

Our discussion of how immigration law changes may affect the skill composition of immigrants is based on a few simple assumptions. To illustrate, let there be two categories of legal immigrants (the unrestricted group of spouses of U.S. citizens $\left(\mathrm{N}_{\mathrm{s}}\right)$ and the numerically restricted employment immigrants $\left(\mathrm{N}_{\mathrm{e}}\right)$ and one group of illegal immigrants $\left(\mathrm{N}_{\mathrm{i}}\right){ }^{25}$ The total number of legal immigrants in any year is $\mathrm{N}_{\mathrm{e}}+\mathrm{N}_{\mathrm{s}}=\mathrm{T}_{\text {legal }}$ while the total number of immigrants equals $\mathrm{N}_{\mathrm{e}}+\mathrm{N}_{\mathrm{s}}+\mathrm{N}_{\mathrm{i}}=$ Total. Using $\mathrm{S}$ to index the average skill of a given type of immigrants, the average skill of all immigrants can be expressed as a weighted average of the skill of the within group categories;

(1) $-S_{\text {legal }}=\left(N_{e} / T_{\text {legal }}\right) S_{e}+\left(N_{s} / T_{\text {legal }}\right) S_{s}$ for average skill of legal immigrants

(2)- $\mathrm{S}_{\text {total }}=\left(\mathrm{N}_{\mathrm{e}} /\right.$ Total $) \mathrm{S}_{\mathrm{e}}+\left(\mathrm{N}_{\mathrm{s}} /\right.$ Tota $) \mathrm{S}_{\mathrm{s}}+\left(\mathrm{N}_{\mathrm{i}} /\right.$ Total $)$ for average skill of all immigrants

To give some content to these expressions, we assume first that $S_{e}>S_{s}>S_{i}$. This ordering follows because the employment visa categories that screen for skills have a more stringent labor market skill threshold than does the spouse category, which in turn has more stringent skill screening than does immigration without any visa (illegal immigration). A prospective immigrant without relatives (siblings, parents, adult children) in the United States faces less stringent employment skill screening by prospective U.S. mates than via the employment visa route to immigration because, for example, charm, looks, and

\footnotetext{
${ }^{25}$ This example easily generalizes when there are many visa categories.
} 
cooking skills may be less rewarded in the labor market than in the marriage market and can make up for deficient earnings abilities. Thus, finding a job match that provides a visa is more costly compared with finding a marital match the lower the prospective immigrant's skill level.

Secondly, we assume that within policy regimes the number of employment visas $\left(\mathrm{N}_{\mathrm{e}}\right)$ are fixed while the number of spouse and illegal immigrant flows are free. Prospective immigrants will select the least cost route to immigration inducing substitution between these categories as the legal regimes shift or economic conditions in the United States or in the sending countries vary. The skill distributions of the immigrant categories overlap and movement between groups on average is from bottom to top (going downwards) and from top to bottom (going upwards). This ordering is reasonable since the prospective immigrants most likely to move between groups are those where the skill overlap between the groups is greatest. For example, if there is an increase in the number of illegal immigrants (due to lower enforcement at the border), the spouse immigrants who move into the illegal category will be the least skilled among the spouse immigrants. Similarly, if there is an increase in the number of employment visas available, the spouses who now obtain employment visas on average will be the most skilled (e.g. the most likely to qualify in the employment category) spousal immigrants.

This framework implies that there will be two effects of any regime change. The first is a composition effect as the relative weights of immigrant categories change. For example, increasing the weight of the employment category will tend to increase the average quality of both legal and total immigrant flows. Similarly, an increase in the relative weight of the illegal immigrants category will reduce the average quality of all immigrants. It may, however, increase the average quality of legal immigrants if some of the low skill spouse immigrants shift into the illegal category. The second effect of any regime change relates to any within group alteration in average skill. Our assumptions imply that the skill levels of husband immigrants will be less than those of employment (principal) immigrants on average, as we see in the data, and greater than those of illegal immigrants. Moreover, allowing more illegal immigration (which does not screen for skills) would lead to a shift of higher skill prospective immigrants out from the marriage route, thus raising the skill level of marital immigrants, while increasing the number of high skill visas would lower the average skill of the marital immigrants. This 
latter indirect substitution effect reduces the overall effect of increasing the number of high-skill visas to the extent that those who would have become immigrants via marriage now do so with an employment visa.

We now use these assumptions to discuss how each of the major specific immigration law regime changes that occurred in the period 1972 through 1995 might have affected the numbers and average skill of yearly immigrant flows. We also directly test in section 6 below how these changes affected the number and skill composition of marital immigrants and the skill composition of employment immigrants. We do not discuss or examine in detail how these law changes affect the numbers of employment principals because the numerical ceilings in this category were usually binding in the years before the 1990 Act, so that, aside from direct effects on the ceilings dictated by law, the only possible kind of effect on the number of male employment principals would be due to shifts in sex composition.

1. The application of the preference category system to the Western Hemisphere (since midyear 1977).

By far, the most complicated change involves the integration of the Western Hemisphere into the worldwide preference category system. The complications stem in part due to the possible differential impacts on each hemisphere, subsequent changes in the integration rules, and different treatment of low skill and high skill employment visa categories. Before integration, there were no employment visa preferences in the WH while the EH operated under a total limit of 34,000 , divided equally between $3^{\text {rd }}$ and $6^{\text {th }}$ preference visas. In 1977 and 1978, a total ceiling of 24,000 was put in place in the WH (once again equal division between $3^{\text {rd }}$ and $6^{\text {th }}$ preferences), but there were no changes in the EH. Starting in 1979 , the two hemispheres were placed under a common limit, initially of 58,000 , falling to 56,000 in 1980 and then becoming fixed at 54,000 thereafter. As before, each of those limits were divided equally between the high and low skill preference visas. Since the pre-1979 within hemisphere limits on employment visas may have been more binding on the $\mathrm{EH}$, the adoption in 1981 of a common limit could result in an effective increase in the number of $\mathrm{EH}$ employment visas.

These changes also had an impact on the two main preferences categories within the employment visas. As described above, third preference visas are for relatively skilled persons and sixth preference 
visas for less skilled persons. While the post 1981 limits were 27,000 in both $3^{\text {rd }}$ and $6^{\text {th }}$ preferences, there was a much higher demand for $3^{\text {rd }}$ preference visas in the $\mathrm{EH}$ and a higher demand for the less skilled $6^{\text {th }}$ preference in the WH.

A. Spouse of U.S. citizens. Bringing the Western Hemisphere under the preference category system for allocating numerically limited visas would of course not directly affect the spouse immigrants. However, via behavioral (substitution) mechanisms, WH individuals who previously would have been admitted under the first-come/first-served with modified screening regime and who now found themselves without a relative or employer sponsor would become candidates for the spouse route to immigration. Thus, there would immediately be an increase in the number of spouse immigrants from the WH. Given that prior to this law change, the Western Hemisphere immigrants underwent some job screening, we would expect that the numerically-limited old-regime Western Hemisphere immigrants had higher skills than spouse immigrants. Accordingly, we would expect that introducing a new flow of previous numerically-limited old-regime immigrants into the spouse pool would increase the average skill level of the WH spouse immigrants. In the Eastern Hemisphere, enlargement of the employment visa allotment due to imposition of a worldwide ceiling in 1979 would reduce pressure on the spouse category, inducing a shift from the spouse route to the employment route. Because dual-eligibles would be more skilled than spouses, we would expect a reduction in the average skill level of the Eastern-Hemisphere husband immigrants.

B. Employment principals. A direct effect of this law change would be to increase the number of employment principals. Its effect on the skill of employment immigrant principals would depend on whether the "new" Western Hemisphere employment immigrants have higher or lower skills than their Eastern Hemisphere counterparts. Previous theory and research both indicate the operation of distance as a selection mechanisms, and, thus, we would expect that the WH employment principals would be less skilled than the EH employment principals and, therefore, that the effect of the WH law change would be to reduce the skill level of employment principals. Moreover, EH immigrants shifting from the spouse category to the employment category in response to the enlarged visa pool would be of lower average skill than the well-screened EH employment immigrants who had not contemplated the spouse route. Thus, 
the average skill of employment immigrants should decrease.

2. Restricting employment-based visas for physicians (1978).

Relative to the total number of visas, the number of physician employment visas issued before the law change was modest and hence its decline in numbers would also be modest. For example, the number of physicians admitted with employment visas hovered about two-thousand in 1976 and 1977, declining to about one-thousand in 1978 and 623 in 1979. Therefore, this law change should have relatively little effect on the total number of employment or spouse visas issued. The major impact stems instead from the changing within group immigrant quality which should lower average immigrant quality.

A. Employment principals. Since the skill and incomes of physician visa immigrants are much higher than those of other employment visa immigrants, the physician restriction should have a sharp direct negative effect on the average skill level of employment principals. Because there are far fewer employment visas than total legal immigrant visas, the effect on average quality of employment principals should be larger than any effect in the quality of all legal immigrants.

B Spouses of U.S. citizens. Restricting the access of physicians to employment visas has no direct effect on the number of spouse immigrants, but it might have behavioral substitution effects. Physicians who are now barred from obtaining employment visas may find the spouse route to immigration attractive, thus increasing the number of spouse immigrants and their average skill. However, if the absolute number of individuals involved is small, then these effects may not be noticeable.

3. IRCA Legalization Programs.

Because they deal explicitly with the illegal population, the IRCA legalization programs do not directly affect either employment or spouse immigrants. But IRCA may have had indirect effects on both, by providing an easier route to legal immigration for both potential spouse and employment immigrants. The nature of these indirect effects would depend on the extent to which the IRCA, employment, and husband pools overlap and on the differences between overlapping segments of the pools.

A. Spouse immigrants. To the extent that IRCA-eligibles are relieved of the obligation to meet stringent job screening, the IRCA programs would reduce the number of spouse immigrants. The direct 
composition effect then is to increase the average quality of non-IRCA legal immigrants. ${ }^{26}$ Whether the IRCA programs increased or decreased the average skill of the spouse immigrants would depend on the skill of the IRCA-eligibles relative to the spouse pool. In general, the registry and pre-1982 resident legalized aliens would have had a long enough time to find a mate, and would obviously have been unsuccessful, implying that their skill level was lower than that of other potential mates for U.S. citizen women. The SAW-legalized aliens, on the other hand, might have included interesting, productive, higher-skilled individuals who with some chutzpah saw the program as an opportunity to enter the U.S., merely by working, or claiming to have worked, a few months in agriculture. If the dual-eligibles were superior to those only eligible for the spouse route, then the IRCA program, which would siphon them off, would reduce the average skill of spouse immigrants. Moreover, if higher-skilled husband-eligibles found the United States less attractive because of the legalization program, then their dropping out of the husband pool would reduce the average skill of husband immigrants.

B. Employment principals. The effect of IRCA on the average skill of employment principals is likely to be negligible, as it is unlikely that low-skill IRCA-eligible immigrants were eligible for employment visas and represented in the backlogs in this visa category.

4. Marriage fraud restriction.

Marriage fraud provisions reduced the number of immigrants coming under spouse visas. Since spouse visa immigrants are less skilled than employment visa immigrants, the direct composition effect is to increase the average quality of legal immigrant flows. The effect on total immigrant flows is muted as some of the now deterred marriages will probably increase illegal immigrant flows. There are indirect within group effects as well.

A. Spouses of U.S. citizens. The marriage fraud provisions were directed at reducing and should unambiguously reduce the number of spouse immigrants. Some of the now deterred more skilled marriage visa types can try to compete for the still numerically limited employment visas reducing the average quality of spouse visas. Some of the now deterred less skilled marriage visa types can branch into the

\footnotetext{
${ }^{26}$ Our INS data files do not include IRCA immigrants.
} 
illegal group which has no explicit numerical limitation, thus increasing the average quality of spouse visas.

B. Employment principals. The marriage fraud provisions, of course, have no direct effect on the number of employment immigrants (which are still numerically fixed), but may have an indirect effect on skill composition due to substitution. Prior to screening for fraud, a less skilled-immigrant selects the marital route over the employment route. With the marital route costs now higher, some of these lower skill spouse immigrants would seek employment visas, thus lowering the average skill level of the latter category. The effect of using an employment visa rather than a marriage visa would be to reduce the average skill of employment immigrants.

5. New employment provisions in the 1990 Act.

The final regime change concerns the 1990 act which had two important direct effectssignificantly increasing the total number of employment visas issued while at the same time reducing the number of unskilled employment visas. By assigning higher weight to the relatively high skilled employment visa categories, the direct compositional effect is to increase the average quality of all legal immigrant and total immigrant flows. In addition, this regime change may have implications due to behavioral substitution effects for flows between categories as well as within category immigrant quality.

A. Employment principals. The 1990 Act dramatically increased the number of visas available to skilled employment immigrants, and equally dramatically reduced the number available to unskilled individuals; and it also made visas available to multinational executives. The 1990 Act should then unambiguously increase the average skill level of employment principals. If we distinguish between the higher and lower skilled subsets of employment principals, then average skill in the higher skilled subset would increase due to the introduction of multinational executives, while average skill in the lower skilled subset would increase only if unskilled persons had dominated the category.

B. Spouses of U.S. citizens. The more indirect behavioral effects involve the implications for the number and type of spouse visas. Increasing the number of employment visas available should generally reduce the pressure on the spouse route; however, reducing the number of employment visas available for unskilled persons should put pressure on the spouse route. It is an empirical question whether, on net, the 
change in the employment visa allotment increases or decreases the number of spouse immigrants. The skill level of spouse immigrants should, however, unambiguously decline, as there is a net outflow to the employment visa category of skilled spouses, but a net inflow into the spouse visa category of low skilled employment visas.

To illustrate the effects of the law changes on the numbers of immigrants in the spouse and employment visa categories, we briefly describe their time series trends. Figure 3 plots the numbers of male employment principal immigrants for the years 1972 to 1995, a category, as noted, which has a series of overall binding numerical ceilings. The shape of this plot is thus almost wholly explained by law changes and processing of visas. Although there exist smaller cyclic swings in this series, ${ }^{27}$ its principal characteristics are a discrete $50 \%$ jump in the series between 1981 and 1982 and an even larger more than two fold jump between 1991 and 1992. Both of these changes are the direct consequence of law changes. The 1981-1982 shift reflects the impact of the extension of the employment preference system to the Western Hemisphere countries. This integration of the $\mathrm{EH}$ and WH under the same set of rules led to an increase in the total numbers of employment visas allowed. Bringing both hemispheres under a single worldwide ceiling starting in 1980 would result in having more visas available to Eastern Hemisphere applicants (who had a high demand for them) and indeed we observe in Figure 3 an increase in employment principals starting in 1982 (consistent with the usual processing and other delays). Similarly, the 1991-1992 shift was the result of the increase in the number of employment visas allowed by legislative change. There was an initially a wide pent-up demand for such slots. After some countries met their demand, the numbers of employment visas began to fall.

Figure 4 plots the other main series of interest-the numbers of male spouses of U.S. citizens. In contrast to the employment visa category, this series has no explicit numerical limits in any year, a reality that is reflected in the volatility of the numbers. Abstracting from the richness of detail in these swings in the numbers, there are two significant movements that we will highlight. The first is the steady and eventually large increase in the numbers of male spousal immigrants from 1981 to 1986 and the second is

\footnotetext{
${ }^{27}$ Although the total numbers of employment visas are fixed within regime, the numbers of male employment visas are not.
} 
the somewhat smaller subsequent decline. The major legislative force in the 1981-1986 upswing was most likely the placement of Western Hemisphere under the preference categories. Potential immigrants from some countries were now effectively constrained and they needed another pathway to become a legal immigrant resident in the United States. The major factors in the post-1986 decline were the passage of the marriage fraud amendments (which made such marriages more difficult) and IRCA which gave some potential immigrants who would have followed the marriage route an alternative path to admission.

Figure 5 provides a more detailed description of the changing bite of the numerical ceilings by plotting the number of employment visas issued for each hemisphere along with the sum of the two. The straight horizontal lines in this figure represent the ceilings that were in place in each year. Before 1976, employment visas (and the ceiling of 34,000) were only relevant for the EH. By the mid 1970s, EH visas issued were actually below the ceiling probably due to severe recession in the U.S. With integration, employment visas were issued to WH countries. Between 1976 and 1981, there was a growth in employment visas in both hemispheres. In both the EH and WH, the growing demand for employment visas did not hit the respective ceilings until 1981. Figure 5 shows that when a single ceiling was introduced in 1981, the sharp jump in employment visas was much larger in the EH. EH demand for employment visas was far greater than in the WH so that the introduction of a single ceiling resulted in a de facto relaxation of the EH ceiling. This differential effect between hemisphere suggests that the impact of these changing rules may vary across hemispheres.

Figures 6 and 7 separate employment visas into their high skill $\left(3^{\text {rd }}\right.$ preference $)$ and low skill $\left(6^{\text {th }}\right.$ preference) components. These figures demonstrate that the large post-1981 increase in demand in the EH were for high skilled $3^{\text {rd }}$ preference visas while the large shift in the WH was for the low skill $6^{\text {th }}$ preference visas. To the extent that behavioral substitution is introduced with spouse visas, they are likely to be relatively high skill EH spouses and low skill WH spouses.

Figure 8 plots time series in the number of spouse visas, separately by hemisphere, and within the WH, separately for Mexico and the rest of the hemisphere. For all three groups, there is a steady climb in the number of such visas following the 1976 integration. However, the sharp decline in marriage visas in the mid to late 1980 s is clearly concentrated in the WH, and within the WH, in Mexico. 
5. Estimating the Effects of Economic Conditions and Law Changes on Numbers of Immigrants and Their Skill Composition

The annual volume of migration flows as well as the skill selectivity of migrants who arrive are not simply consequences of the specific provisions of U.S. immigration laws. Prospective migrants decide to come or not based in part on a comparison of economic conditions in their home countries and in the U.S., the costs of migration, and the psychic benefits and costs of living in different places. In a recent paper, we developed a theoretical framework which identifies some of the principal economic forces shaping the economic selectivity of immigrants and the gains they experience from migration. ${ }^{28}$ This theoretical framework identifies the interaction between migrant skill heterogeneity and differences in the valuations of skills across countries of the world as important determinants of the numbers of migrants as well as their skill selectivity. For example, holding worker skill levels constant, prospective migrants from countries with low skill prices (relative to the United States) have more to gain from migrating to the U.S. Since low skill prices will enable even less skill workers to gain from migration, the model also predicts a positive correlation of origin country specific skill prices and the average skill of migrants from those countries. Similarly, high costs of migration will not only reduce the number of migrations, but will also increase the average skill of migrants since (at any given skill price) only high skill migrants will gain enough to justify the move. In summary, this theoretical framework argues that skill price heterogeneity across sending counties, differential direct migration costs and the selective criteria of U.S. immigration laws influence not only the numbers of migrants from different countries but selectively the skill composition of those who migrate.

\section{A. Data and Measures.}

To assess how and whether changes in U.S. immigration law regimes and country-specific economic conditions have importantly shaped the changing skill composition of U.S. immigrants, we constructed country (of birth)-specific data sets for the period 1972 through 1992 that merge information on the new legal immigrants from the INS data sets, information on the major immigration law regimes,

\footnotetext{
${ }^{28}$ See "Determinants of Immigrants’ Economic Gains from Immigration," Jasso, Rosenzweig, and Smith (1998).
} 
and information on the origin country characteristics of the immigrants. ${ }^{29} \mathrm{We}$ focus on two subsets of immigrants, spouse-of-citizen immigrants and employment-based principals. The set of spouse immigrants covers all numerically-unlimited immediate-relative spouse visas, including fiancé visas and the new visas for widowed persons made available by the 1990 Act. ${ }^{30}$ The set of employment principals covers the principals in the old system's third and sixth preference categories (for the Fiscal Years 19721991 ) and in the new 1990 Act system's employment first, second, and third preference categories but, for consistency, excluding visa classes set aside for persons from particular countries. ${ }^{31}$

For each country of origin for each year, we obtained the average occupational earnings, constructed from the reported occupation codes as discussed above for all male immigrants in the relevant visa category aged 21-65. As noted, occupation is the single indicator of skill available in these data. Occupation represents the occupation reported by the immigrant. If the immigrant is obtaining a visa requiring labor certification (for example, if he is an employment-based principal), then the reported occupation is the occupation on which the labor certification is based. Otherwise, occupation refers to the current or last employment in the origin country or in the United States. Because immigrants adjusting their visa status are more likely to report a U.S. occupation and to have some U.S. work experience, we also constructed for each country a variable indicating the proportion of men in the visa category who

\footnotetext{
${ }^{29}$ We received defective data for FY 1988 , such that one-third of the records are missing. Accordingly, we do not use FY 1988 data in this paper, but will re-do all analyses as soon as we receive the correct data set. Moreover, given that data for Fiscal Years 1980 and 1981 are irremediably incomplete, we control by defining a binary variable for those years (incomplete data).

${ }^{30}$ The visa classes included in the spouse set are: IR1, IR6, IF1, MR6, CR1, CR6, CF1, IW1, and IW6.

${ }^{31}$ As noted in official State Department publications, the old employment categories correspond to the new system's employment first, second, and third categories (U.S. Department of State 1992). Legislation subsequently enacted (in October 1992) provided visas for two country-specific groups, nationals of the People's Republic of China who had been in the United States between 4 June 1989 and 11 April 1990 (mostly students who did not want to return to China after the Tiananmen Square confrontation) and scientists from the independent states of the former Soviet Union and the Baltic States, the visas to be drawn from employment second preference for the Soviet scientists and from the employment third preference for the Chinese students. For comparability with the employment series since 1972, we exclude both those groups. Accordingly, the visa classes included in the employment principal set are: P31, P36, P61, P66, E11, E12, E13, E16, E17, E18, E21, E26, E31, E32, E36, E37, EW3, and EW8.
} 
adjusted their status. ${ }^{32}$

The rate of reporting an occupation has changed over time. It appears to be linked to adjustment of status and to the possibility that the adjusting immigrant is working illegally. Visa applicants who are already in the United States and who are working illegally might be reluctant to provide their occupation on the application forms. To capture trends in reporting bias, we thus constructed a variable indicating the proportion of the immigrants who reported an occupation.

Country-specific skill prices are not directly observable. However, it is possible to infer how skill prices vary across countries with information on the individual earnings and schooling of workers across origin countries and country-specific data on aggregate output, numbers of workers and average schooling levels ${ }^{33}$. With respect to inter-country skill price variation, among workers with the same schooling and residing in countries with the same output per worker, those workers residing in countries where workers also have average skill levels will have lower skill prices and wages, while among workers with identical schooling levels in countries with the same average worker skill levels, those in counties with higher output per worker will have higher skill prices and observed wages. Given immigrant skill heterogeneity and selectivity due to home-country skill price variation, these results imply that immigrants from countries with high (low) average levels of schooling will have the highest (lowest) skill levels among immigrants with identical schooling levels.

To characterize the origin countries' migration-relevant conditions and to measure skill prices , we use their year-specific Gross Domestic Product (GDP) per worker estimates from the Penn World Table, Mark 5.6 and estimates of the average schooling levels of the working age population in origin countries from Barro and Lee (1993). These country specific GDP measures were adjusted for purchasing power parity (PPP) and expressed in 1985 U.S. dollars. The series we use omits some countries (notably China, Vietnam, Cuba and countries of the former Soviet Union). Since the theoretical model is symmetric in terms of attributes of destination and origin countries, our models also include variables

\footnotetext{
${ }^{32}$ There is also a variable (not reported in Tables 6 and 7) controlling for missing adjustment status.

${ }^{33}$ See Jasso, Rosenzweig, and Smith (1998) for details.
} 
measuring time series variation in GDP per worker and average schooling per worker in the United States.

Table 4 provides descriptive statistics for the data sets constructed. The table indicates, consistent with our assumption about differential screening, that over the period the average earnings of the husband immigrants, as measured by the occupational income measure, were about $22 \%$ less than those of all employment principal men, and almost $30 \%$ less than those of principal immigrant men in the high skill visa category and less as well, by $7 \%$, than those for low skill employment immigrants. Some of this difference may be due to age, as the average age of the employment immigrants is over 5 years more $(15 \%)$ than that of the husband immigrants. In addition, a considerably higher proportion of the high-skill employment immigrants adjusted status -- $66 \%$ compared with $39 \%$ for the husband immigrants, so the former group may have more U.S. labor market experience. Not surprising, almost all of the employment immigrants report an occupation, while on average $77 \%$ of the husband immigrants do so. Finally, over the period employment immigrants came from larger countries with a higher mean per-capita GDP than did the husband immigrants.

\section{B. Estimation Procedure}

Based on the constructed country data set, we estimate the determinants of the country- and yearspecific number (per origin country population) and average occupational earnings of immigrant men age 21-65 who entered by marrying U.S. citizens. We also estimate the determinants of the average occupational earnings of similarly-aged men in the employment visa category, stratified by high and low skill immigrants; as discussed above, in these employment regressions the Western Hemisphere observations start in 1977. The regressors include origin-country and U.S. GDP and average schooling per worker and the law-regime factors discussed above depicted by sets of dummy variables corresponding to the different regimes. We also include in the specification a cohort term designed to capture a linear time trend and, in the occupational earnings equations, a variable measuring the proportion of immigrants reporting an occupation. ${ }^{34}$ The specification also includes country fixed effects,

\footnotetext{
${ }^{34}$ Consistent with our discussion above of occupation coding, the skill equation also includes a dummy for the years when INS coded occupation using the 1960 or 1970 Census detailed occupational classifications (Fiscal Years 1972-1982).
} 
to pick up such time-invariant factors as distance of the country from the United States, language and unmeasured cultural factors that may affect skill levels of immigrants by country.

In an earlier section, we described in detail the major shifts in U.S. immigration law regimes. Identification of these regime shifts in our statistical model can only flow from calender years shifts in the underlying relationship. It would be useful to be able to formulate and implement a sharp characterization of the law regimes. However, two factors conspire against it: First, important law changes sometimes occur together, such as i) worldwide visa allocation integration and physician restriction, and (ii) IRCA legalization and the marriage fraud restrictions. Second, defective data for three years -- Fiscal Years $1980,1981,1988$, the first two of which are beyond repair -- make it necessary to exclude the FY 1988 observations altogether and to define a dummy variable for the 1980 and 1981 years, thus hampering identification of more precise law-regime effects. Fortunately, the coincident regime shifts should have similar effects. Therefore, we characterize the law regimes and estimate their effects with two main binary variables: (i) integration of the two hemispheres into a single worldwide visa allocation system, including the physician restriction provision, equal to one if the year is FY 1977 or later; and (ii) IRCA legalization and marriage fraud restriction, equal to one if the year is FY 1987 or later. Each of these variables is defined for one or both hemispheres, as appropriate. For example, in the employment regressions, in which Western Hemisphere observations begin in FY 1977 (when the preference category system was extended to the Western Hemisphere), the worldwide integration variable is defined only for the Eastern Hemisphere; in the marriage regressions, however, this same variable is defined for both hemispheres.

The data series on the size of the workforce in sending countries are only available up to 1990. Therefore, it is not possible to test for the effect of changes in the 1990 act simultaneously with country of origin economic conditions. Fortunately, the changes induced by the 1990 act are so large that its main impact on immigrant quality is not in dispute. This act more than doubled the number of employment immigrants so that its principal composition effect was to raise average immigrant quality. Empirically, figure 5 shows that the large increase in employment visas was concentrated in Eastern Hemispheres countries while figure 8 demonstrates that the steady secular increase in spouse visas slowed or stopped about this time (again especially in the East). As mentioned above, there were possible within-group skill 
effects as well. To examine this question, table 5 lists measures of occupation incomes for employment principal and male spouses visas in the years immediately before and after the year in which the act became effective. In addition to the large increase in the numbers of immigrants, the 1990 act shifted the composition of employment principal immigrants toward the more skilled. That implication is confirmed in Table 5 as the occupation incomes of employment visas in both hemispheres are higher after the act became effective than before. This increase in occupation incomes of employment visas was greater in the WH, suggesting that the principal impact on within-group skill may flow from the restriction on low skill employment visas-a restriction that was more relevant in the WH. We also anticipated a larger reduction in the skill of spouse immigrants in the WH since the reduction in the number of unskilled visas lead to a greater inflow of them into the spousal category in the WH.

\section{Results}

Table 6 reports the fixed-effects estimates for the husbands of immigrants. The first column lists estimates for the ratio of the number of husband immigrants to the origin-country population, and the second column reports the coefficients for the average occupational earnings of those immigrants. As explained above, the gains to migration- and consequently the larger the number of migrants per countryare positively related to U.S. skill prices and negatively correlated with skill prices in sending countries. Our empirical estimates for origin country economic variables support these theoretical expectations. A higher per-capita income in the origin country leads to a statistically significant drop in out-migration rates while (holding constant GDP) an increase in average schooling increases the number of male spouse migrants to the U.S. Similarly, an increase in sending country specific schooling per worker (holding constant GDP) lowers skill prices and makes immigration more advantageous for lower skilled workers. This prediction is supported by the statistically significant effect of country schooling in the model for ln earnings listed in the second column of table 6 . Not surprisingly, it is more difficult to obtain robust estimates for the U.S counterpart variables since we must rely on time series variation in two collinear series (GDP and average schooling per worker) which are in common to all sending countries.. Yet, even here, we obtain a statistically significant negative effect on U.S. education per worker implying that lower 
skill prices in the U.S. discourage international migration to America. However, we are unable to detect any effects of the U.S. economic variables in the income model no doubt due to the collinearity in the two variables.

The immigration law regime variables indicate both direct and indirect effects of law regime changes. As was expected, the regression results in table 6 show differential effects by hemisphere. In the $\mathrm{EH}$, the integration of preferences lead to an effective increase in employment visas, easing the pressures on marriage visas there. However, applying the preference system to the Western Hemisphere should increase the number of husband immigrants per country (in the Western Hemisphere). Such additional WH immigrants added to the pool at that time were evidently more skilled (there was implicit skill screening of WH applicants before integration) raising the average quality of WH spousal immigrants. However, we find no effect on average quality of spouses integration in the East.

Similarly, the combined legislation cracking down on marriage fraud and IRCA had a statistically significant depressing effect on the number of spouse immigrants, equally for WH and other immigrantorigin immigrants. If the dominant substitution induced by the lowering of fraudulent marriages is to increase illegals (employment visas), then average quality of the remaining marriage visas should rise (fall). The impact of fewer prospective immigrants who decide not to marry a U.S. citizen due to IRCA should increase the average quality of the remaining spouse visas. Our empirical estimates indicate that the combined effects of IRCA and movement into illegals dominated for the EH (increasing average quality of marriages) while movement into employment may have dominated in the WH where average quality of marriages declined.

Table 7 presents the estimates for the average occupational earnings of the employment immigrants, in total and stratified by skill level. Decreasing skill prices in sending countries or increasing skill prices in the U.S. should, though immigrant selectivity, lower the average quality of employment immigrants. The negative estimated coefficient on origin- country GDP and positive coefficient on U.S. GDP per worker both support this hypothesis, especially in the all employment column.

The coefficients estimated in table 7 suggest no net effect of expansion in employment immigrants in the EH. This may reflect offsetting effects of the expanding pool lowering within group 
quality on the margin and the fact the more skilled visas were increasingly used in the EH. Our results in table 6 indicated that there may have been an increase flow in the WH into employment visas that lowered the average quality of marriage. The results in table 7 indicate, interestingly, the marriage fraud legislation may have decreased average skill levels in both the husband and employment visa categories for WH immigrants - such immigrants were evidently of above-average skill among spouse immigrants but below average skill among employment immigrants. Finally, there is a strong EH trend toward higher within group quality of employment visas. We know from figures 6 and 7 that the EH was able to increasingly compete effectively against the WH for the high skill visas.

\section{Conclusion.}

This paper has re-examined one of the central question in immigration research in the last few decades-secular trends in the 'labor market quality' of new immigrants. Based on the conventional surveys used to examine this question, an almost universal consensus has been reached-the labor market quality of new recent immigrants is quite low and has been declining relative to skills of native-born Americans. Despite their widespread use, we argue in this paper that these conventional surveys provide quite flawed data for this question. These data are flawed because it is impossible to determine when the foreign-born population in these conventional surveys actually arrived in the United States and therefore how recent they actually are. The data are also deficient since a significant fraction of the foreign-born population included in these surveys are not legal immigrants at all, but instead represent an uncertain amalgam of legal, illegal, and nonimmigrant populations. In our view, these data problems are sufficiently serious to call into question most prior research on this question. Another serious problem with most existing research is that, somewhat remarkably, it deals with this issue without any recognition or discussion of the legal rules governing the number of immigrants who may enter and the criteria by which they are selected. In part, this neglect of the legal environment is because convention labor market surveys do not distinguish the foreign-born population by visa-type.

Given these problems with conventional labor market surveys, we turn to an alternative data 
resource-INS records of legal immigrants over the period 1972 through 1995-that allows us to examine not only the changing skill composition of legal immigrants, but also how these changes were influenced by alterations in immigration law regimes and changing economic conditions in sending countries and the U.S. These data paint a quite different portrait of the labor market quality of legal immigrants. First, especially if we abstract from the special refugee and asylee population, during most of the last twentyfive years, the labor market quality of male legal immigrants has been as high or higher than that of male native-born workers. Second, while the relative labor market quality of male legal immigrants was falling during the 1970 s and early 1980 s, there has been a steady rise in the quality of legal immigrants during the last half of the 1980s and throughout the 1990s.

In this paper, we also examined the reasons for these secular trends in the labor market quality of legal immigrants. In our view, these trends result both from a series of changes in the legal regime governing immigration to the U.S. and behavioral choices made by prospective immigrants (and the migrant skill selectivity that results from those choices) in light of changing economic conditions in sending countries and the U.S. In addition to a large influx of refugees, there were two regime changes which contributed to the early period of declining labor market quality of immigrants. Legislation enacted in 1976 which extended the preference system to the Western Hemisphere helped produce a large increase in the number of visas for permanent residence obtained by marrying a U.S. citizen. While having little effect on overall numbers, a separate 1976 law severely restricted the granting of employment visas to foreign physicians thereby lowering the average skill of legal immigrants. Similarly, there were three principal changes in the legal rules which helped produce the post-1986 rise in labor market quality of legal immigrants. First, the Marriage Fraud act which lead to a decline (especially among residents of Mexico) in the numbers of people who become permanent residents by marrying U.S. citizens. Second, IRCA , by easing one route to legalization apparently made the alternative path of marriage to U.S. citizens less attractive. Finally, the Immigration Act of 1990 almost trebled the ceilings for the relatively high skilled employment visas while at the same time reducing the numbers of low skill employment visas issued.

Legal regime changes alone cannot fully explain secular trends in the numbers and quality of 
legal immigrants. The annual volume of migration flows and the skill selectivity of migrants who arrive also are based on comparisons of economic conditions in sending countries and the U.S. This is especially true in the numerically unrestricted category of those who obtain permanent resident visas by marrying U.S. citizens. The empirical estimates summarized in this paper are consistent with our theoretical framework. First, the volume of migration per capita is positively associated with lower sending-country skill prices. In addition, the average skills of migrants decline as sending country skill prices (and migration costs) fall relative to those skill price in the U.S. Both our theoretical and empirical models imply that trends in the average labor market quality of immigrants are a negative function of the skill price gap between potential sending countries and the U.S. For example, rising skill prices in sending countries (relative to the U.S.) since the mid 1980s contributed to the rising labor market quality of legal immigrants. 


\section{REFERENCES}

Barrett, Alan. 1996. "Did the Decline Continue? Comparing the Labor-Market Quality of United States Immigrants from the Late 1970's and Late 1980's, "Journal of Population Economics, 9:57-63.

Duleep, Harriet Orcutt, and Mark C. Regets. 1996. "Admission Criteria and Immigrant Earnings Profiles." International Migration Review 30:571-590.

Funkhauser, Edward, and Stephen J. Trejo. 1995. "The Labor Market Skills of Recent Male Immigrants: Evidence from the Current Population Survey." Industrial and Labor Relations Review 48:792811.

Jasso, G., D. F. Massey, Mark R. Rosenzweig, and James P. Smith. 1997. "Preliminary Results from the New Immigrant Survey." Paper presented at the 1997 Joint Meeting of the Public Health Conference on Records and Statistics and the Data Users Conference, Washington, DC, July 1997.

Jasso, Guillermina., Mark. R. Rosenzweig, and James P. Smith. 1998. "Determinants of Immigrants“ Gains from Immigration," May 1998.

Jasso, Guillermina, and Mark R. Rosenzweig. 1986. "What's in a Name? Country-of-Origin Influences on the Earnings of Immigrants in the United States." Research in Human Capital and Development 4:75-106.

Jasso, Guillermina, and Mark R. Rosenzweig. 1988. "How Well Do U.S. Immigrants Do? Vintage Effects, Emigration Selectivity, and Occupational Mobility." Research in Population Economics 6:229-253.

Jasso, Guillermina, and Mark R. Rosenzweig. 1995. "Do Immigrants Screened for Skills Do Better Than Family-Reunification Immigrants?" International Migration Review 29:85-111.

Mines, Richard, Susan Gabbard, and Anne Steirman. 1997. "A Profile of U.S. Farm Workers:

Demographics, Household Composition, Income and Use of Services." Washington, DC: U.S. Department of Labor.

Passell, Jeffrey, "Estimates of Undocumented Immigrants in 1995," unpublished paper, Urban Institute. 
Smith, James P., and Barry Edmonston (eds.). 1997. The New Americans: Economic, Demographic, and Fiscal Effects of Immigration. Report of the National Research Council. Washington, DC: National Academy Press.

Summers, Robert, and Alan Heston. 1991. "The Penn World Table (Mark 5): An Expanded Set of International Comparisons, 1950-1988." Quarterly Journal of Economics 106:327-368.

U.S. Department of Justice. 1997. "Immigrants Admitted into the United States as Legal Permanent Residents, Fiscal Year 1972 through Fiscal Year 1995." Springfield, VA: National Technical Information Service.

U.S. Department of State. 1992. 1991 Report of the Visa Office. Department of State Publication 9823. Washington, DC: Department of State, Bureau of Consular Affairs.

U.S. Immigration and Naturalization Service. 1943-1978. Annual Report of the Immigration and Naturalization Service. Washington, DC: U.S. Government Printing Office. 1979-1992. Statistical Yearbook of the Immigration and Naturalization Service. Washington, DC: U.S. Government Printing Office. 
Table 1. Average Occupation Income, 1970-1990 U.S. Censuses (Recent Immigrants)

\begin{tabular}{cccc}
\hline \hline Years of Experience & 1970 & 1980 & 1990 \\
\hline $1-5$ & 19,899 & 19,002 & 18,485 \\
$1-3$ & NA & NA & 18,714 \\
$4-5$ & NA & NA & 18,172 \\
\hline
\end{tabular}


Table 2. Descriptive Statistics 1970-1990 U.S. Censuses (Recent Immigrants)

\begin{tabular}{|c|c|c|c|}
\hline Country of Birth & 1970 & 1980 & 1990 \\
\hline \multicolumn{4}{|c|}{ Percent of Population } \\
\hline Mexico & 29.6 & 36.7 & 37.3 \\
\hline Other North America & 5.2 & 5.0 & 11.4 \\
\hline South America & 7.2 & 5.2 & 6.2 \\
\hline Europe & 31.8 & 11.8 & 11.5 \\
\hline Asia & 23.2 & 36.2 & 29.7 \\
\hline Africa & 1.3 & 4.0 & 3.2 \\
\hline Oceania & 1.6 & 0.1 & 0.7 \\
\hline \multicolumn{4}{|c|}{ Average Occupation Income (\$) } \\
\hline Mexico & 17,734 & 17,187 & 16,804 \\
\hline Other North America & 21,862 & 19,694 & 17,843 \\
\hline South America & 19,517 & 19,481 & 18,361 \\
\hline Europe & 19,358 & 20,282 & 20,393 \\
\hline Asia & 23,290 & 20,151 & 20,098 \\
\hline Africa & 21,970 & 21,080 & 19,959 \\
\hline Oceania & 20,264 & 19,590 & 20,336 \\
\hline \multicolumn{4}{|c|}{ Average Education (Years) } \\
\hline Mexico & 8.88 & 8.75 & 9.26 \\
\hline Other North America & 13.06 & 11.65 & 10.25 \\
\hline South America & 12.05 & 13.10 & 12.45 \\
\hline Europe & 10.81 & 12.95 & 13.93 \\
\hline Asia & 14.69 & 13.80 & 13.71 \\
\hline Africa & 14.52 & 15.42 & 14.20 \\
\hline Oceania & 9.95 & 13.64 & 13.83 \\
\hline All & 11.38 & 11.77 & 11.62 \\
\hline
\end{tabular}


Table 3. Average Occupation Income 1994-97 CPS (Recent Immigrants)

\begin{tabular}{rrrrr}
\hline \hline & \multicolumn{5}{c}{ CPS Year } \\
Years Since & 1994 & 1995 & 1996 & 1997 \\
\hline All & 18,467 & 18,661 & 18,751 & 19,028 \\
1994 -current & NA & NA & 19,375 & 19,156 \\
$1992-93$ & NA & NA & 18,634 & 18,832 \\
1992 -current & 18,740 & 18,853 & NA & \\
$1990-91$ & 18,608 & 18,408 & 18,307 & \\
$1988-89$ & 18,168 & & & 739 \\
$\mathrm{~N}$ & 1,096 & 845 & 807 & \\
\hline
\end{tabular}


Table 4. Characteristics of Legal Male Immigrants Age 21-65, by Visa Category: 1972-1992

\begin{tabular}{lcccc}
\hline \hline & & \multicolumn{2}{c}{ Principal Men with Employment Visas } \\
\cline { 5 - 5 } Variable & Husbands of & All & "High Skill" & "Low Skill" \\
\hline Mean occupational income & 18,943 & 24,195 & 27,061 & 20,466 \\
(1979 US\$) & $(2,039)$ & $(3,902)$ & $(4,492)$ & $(2,801)$ \\
Mean age & 30.3 & 35.7 & 35.1 & 36.5 \\
& $(2.18)$ & $(3.00)$ & $(3.22)$ & $(3.46)$ \\
Proportion adjusting status & .389 & .529 & .659 & .360 \\
& $(.204)$ & $(.220)$ & $(.236)$ & $(.269)$ \\
Proportion reporting an & .770 & .971 & .965 & .976 \\
occupation & $(.152)$ & $(.0467)$ & $(.0500)$ & $(.0538)$ \\
Mean per-capita PPP GDP (1985 & 5,389 & 5,663 & 5,372 & 6,044 \\
US\$) of country of birth & $(3860)$ & $(4,765)$ & $(5,001)$ & $(4,408)$ \\
Mean population size $(000$ 's) of & 68,758 & 20,5567 & 24,8081 & 149,945 \\
country of birth & $(48,679)$ & $(33,1207)$ & $(35,7946)$ & $(283,084)$ \\
\hline Number of observations & 2,369 & 1,982 & 1,782 & 1,811 \\
\hline
\end{tabular}

Notes: Standard deviation in parentheses. 
Table 5. Average Occupational Income Among Spouse and Employment Principal Immigrants Before and After the 1990 Act: Men Age 21-65

\begin{tabular}{||l|c|c|c|c||}
\hline Hemisphere of Origin & \multicolumn{5}{|c||}{ Cohort } \\
\cline { 2 - 5 } & $\mathbf{1 9 9 0}$ & $\mathbf{1 9 9 1}$ & $\mathbf{1 9 9 2}$ & $\mathbf{1 9 9 3}$ \\
\hline \hline A. Spouses of U.S. Citizens \\
\hline Eastern Hemisphere & 20,355 & 20,613 & 20,661 & 20,706 \\
\hline Western Hemisphere & 17,868 & 18,092 & 18,043 & 17,572 \\
\hline \hline B. Employment Principals & 23,006 & 23,483 & 24,043 & 24,152 \\
\hline Eastern Hemisphere & 20,599 & 19,179 & 21,469 & 21,802 \\
\hline Western Hemisphere & & & & \\
\hline
\end{tabular}

Note: The 1990 Act took effect at the start of Fiscal Year 1992. 
Table 6. F.E. Estimates: Immigrant Men Who Are Husbands of U.S. Citizens, 1972-1990

\begin{tabular}{|c|c|c|}
\hline Variable & $\begin{array}{l}\text { Immigrants/Home- } \\
\text { Country Population }\end{array}$ & $\begin{array}{c}\text { Log of Average } \\
\text { Occupational Earnings }\end{array}$ \\
\hline \multicolumn{3}{|l|}{ Origin country and U.S. economic variables } \\
\hline $\begin{array}{l}\text { Origin-country PPP GDP per-worker } \\
\text { (1985 dollars) }\end{array}$ & $\begin{array}{l}-.0162 \\
(3.33)\end{array}$ & $\begin{array}{l}.0075 \\
(0.39)\end{array}$ \\
\hline Origin-country average $\ln$ education & $\begin{array}{l}.0065 \\
(1.58)\end{array}$ & $\begin{array}{l}-.0856 \\
(3.22)\end{array}$ \\
\hline U.S. GDP per-worker (1985 dollars) & $\begin{array}{l}-.0099 \\
(0.19)\end{array}$ & $\begin{array}{l}.0006 \\
(0.07)\end{array}$ \\
\hline U.S. In education per worker & $\begin{array}{l}-.0899 \\
(2.82)\end{array}$ & $\begin{array}{l}-.1938 \\
(0.47)\end{array}$ \\
\hline Time trend & $\begin{array}{l}.0016 \\
(3.01)\end{array}$ & $\begin{array}{l}.0358 \\
(1.24)\end{array}$ \\
\hline $\begin{array}{l}\text { Proportion of immigrants who adjusted } \\
\text { status }\end{array}$ & - & $\begin{array}{l}-.0075 \\
(0.09)\end{array}$ \\
\hline Proportion reporting an occupation. & - & $\begin{array}{l}-.0130 \\
(0.27)\end{array}$ \\
\hline 1970 occupational categories & - & $\begin{array}{l}.0609 \\
(3.85)\end{array}$ \\
\hline Incomplete data years & $\begin{array}{l}-.0153 \\
(1.74)\end{array}$ & $\begin{array}{l}.0044 \\
(0.63)\end{array}$ \\
\hline \multicolumn{3}{|l|}{ U.S. Immigration law regime } \\
\hline Preference system & $\begin{array}{l}-.0024 \\
(1.92)\end{array}$ & $\begin{array}{l}.0035 \\
(0.36)\end{array}$ \\
\hline Preference system $* \mathrm{WH}$ & $\begin{array}{l}.0145 \\
(1.39)\end{array}$ & $\begin{array}{l}.0345 \\
(2.21)\end{array}$ \\
\hline Marriage Fraud-IRCA legalization & $\begin{array}{l}-.0048 \\
(2.43)\end{array}$ & $\begin{array}{l}.0159 \\
(2.32)\end{array}$ \\
\hline Marriage Fraud-IRCA legalization*WH & $\begin{array}{l}.0003 \\
(0.06)\end{array}$ & $\begin{array}{l}-.0307 \\
(1.51)\end{array}$ \\
\hline
\end{tabular}

Notes: Absolute values of robust t-ratios in parentheses. Number of observations $=2387$. Number of countries $=145$. Income observations are weighted by the number of immigrants. 
Table 7. F.E. Estimates:Log of Average Occupational Earnings for Immigrant Principal Men with Employment Visas, 1972-1990

\begin{tabular}{|c|c|}
\hline Variable & All Employment \\
\hline \multicolumn{2}{|l|}{ Origin country and U.S. economic variables } \\
\hline $\begin{array}{l}\text { Origin-country PPP GDP per-worker } \\
\text { (1985 dollars) }\end{array}$ & $\begin{array}{l}-.0215 \\
(0.38)\end{array}$ \\
\hline Origin-country average $\ln$ education & $\begin{array}{l}-.3015 \\
(3.11)\end{array}$ \\
\hline U.S. GDP per-worker (1985 dollars) & $\begin{array}{l}.1928 \\
(1.79)\end{array}$ \\
\hline U.S. In education per worker & $\begin{array}{l}-1.301 \\
(0.99)\end{array}$ \\
\hline Time trend & $\begin{array}{l}-.0146 \\
(1.35)\end{array}$ \\
\hline $\begin{array}{l}\text { Proportion of immigrants who adjusted } \\
\text { status }\end{array}$ & $\begin{array}{l}.2676 \\
(1.20)\end{array}$ \\
\hline Proportion reporting an occupation. & $\begin{array}{c}.0879 \\
(0.63)\end{array}$ \\
\hline 1970 occupational categories & $\begin{array}{l}-.0008 \\
(0.54)\end{array}$ \\
\hline Incomplete Years & $\begin{array}{l}-.0332 \\
(2.54)\end{array}$ \\
\hline \multicolumn{2}{|l|}{ U.S. Immigration law regime } \\
\hline Preference system $* \mathrm{EH}$ & $\begin{array}{l}.0080 \\
(0.37)\end{array}$ \\
\hline Marriage Fraud-IRCA legalization & $\begin{array}{l}-.0293 \\
(1.20)\end{array}$ \\
\hline Marriage Fraud-IRCA legalization*EH & $\begin{array}{l}.0669 \\
(3.77)\end{array}$ \\
\hline
\end{tabular}

Notes: Absolute values of robust t-ratios in parentheses.. Number of observations $=2387$. Number of countries $=145$. Income observations are weighted by the number of immigrants. 